\title{
Andreas Hatzigeorgiou* \\ Can Sports Promote Exports? The Role of Soccer Matches in International Trade
}

DOI 10.1515/gej-2015-0029

Abstract: Sports can help to increase foreign trade and promote global economic integration. Engaging in sports can provide visibility opportunities for countries and may spur the interest of firms as well as consumers in the respective foreign market. Sport could also help to infuse trust into cross-country business relationships. While previous studies have investigated the role of sport events on trade, this study analyzes whether countries can increase trade between them by engaging in sporting activities with each other. We use soccer, being the world's most popular sport, as an example when investigating this potential bilateral sport-trade link. Our empirical strategy builds on the fact that many soccer matches between countries' national teams are the result of a random drawing procedure. Thus, they are a possible source of exogenous variation. Using a gravity model framework, we test the proposed link for approximately 4,800 soccer matches that were played between 209 countries during the period 1995 through 2001. We also analyze the hypothesized underlying impact channel by estimating the impact on trade for goods that are likely to have different elasticity with respect to information and trust friction. The results are indicative of the hypothesis that countries that engage in sporting activities with each other enhance their bilateral trade. These results could have potentially interesting policy implications. Governments may want to consider actively promoting sporting activities together with countries with which they want to enhance their trade.

Keywords: trade, sport, trade costs, soccer, gravity model, information, trade promotion

JEL Classification: F14, L83

*Corresponding author: Andreas Hatzigeorgiou, The Ratio Institute, Stockholm, Sweden;

Stockholm Chamber of Commerce, Stockholm, Sweden, E-mail: ah@ratio.se 


\section{Introduction}

I think the big issue everywhere in the world today is there are some forces bringing us together and some forces tearing us apart. And you want the ones that are bringing us together - like soccer, which provides a constructive, entertaining and safe means of working out some conflicts - to triumph over the ones that are tearing us apart.

- Bill Clinton (following the US soccer team's advancement in the 2010 World Cup)

While the idea that sport may help to bridge cultural differences and bring nations and societies closer together is widely recognized, the notion that sport could be an important factor for encouraging commercial relationships and trade between nations is not nearly as ubiquitous.

Trade costs still inhibit trade (e.g., Anderson and van Wincoop 2004; Bernard, Redding, and Schott 2007; Hummels and Schaur 2012). But, trade has been changing in character over the past few decades in ways that have diminished the role of conventional trade barriers whilst increasing the importance of informal trade barriers, such as information frictions, lack of visibility and exposure in international markets as well as insufficient trust between sellers and buyers of different countries. Anderson and can Wincoop (2003) suggested that informal trade barriers currently exceed conventional barriers to trade as drivers of trade costs. ${ }^{1}$

This trend raises the question whether sport may not only bring nations and peoples "closer together," but also reduce trade costs. The fact that an estimated 329 million TV viewers around the world watched the 2010 FIFA World Cup final constitutes one distinct example for why sport has the potential to provide countries as well as firms with visibility and exposure in foreign markets, which could spur trade. Furthermore, increased tourism is often a result of sporting events and this may provide another channel through which trading relationships between nations that interact through sport can be initiated and improved.

To our knowledge, this is the first study which explores the role of countries' engagement in sport activities with each other on trade between them. The analysis is conducted by applying a gravity model to a comprehensive dataset with information on around 4,800 soccer matches played between 209 countries between the years 1995 and 2001. The results demonstrate a positive and statistically significant relationship between the number of soccer matches

1 Some evidence on the importance of informal trade barriers was provided by Kneller and Pisu (2011) for firms in the United Kingdom and the Swedish National Board of Trade (2011) for firms in Sweden. 
played between countries and their trade. Because soccer matches, especially those played in connection to international tournaments, are likely to be exogenous with respect to trade, inferences can be drawn on the causal effect of sport on bilateral trade, which adds to the novelty of this study. The potential channel through which sport is conjectured to influence trade is tested by examining the impact for separate sets of goods that presumably respond differently to information and trust frictions. In doing so we can test the validity of the hypothesis that sport influences trade through the information and network channel.

The paper is organized as follows: Section 2 presents a conceptual framework and reviews some related studies. Section 3 describes the data, explains the empirical model and discusses the approach used for estimation. Section 4 discusses the main results and provides further support for the robustness of the findings. Section 5 concludes and gives some final remarks.

\section{Conceptual Framework and Related Research}

Insufficient information about foreign markets may deter a firm from engaging in foreign trade or undermine a firm's ability to identify market opportunities abroad. It can be particularly difficult for a firm to obtain information about foreign markets whose language, business culture, regulatory system and institutions differ from those of the home country (e. g., Schneider 1988; Elsass and Veiga 1994; Hofstede, 2001; Hummels and Klenow 2005; Melitz 2008; Egger and Lassmann 2012). A lack of trust between sellers and buyers from different countries, as well as weak institutions, raise trade costs and can undermine business profits (Anderson and Marcouiller 2002; Guiso, Sapienza, and Zingales 2009). Moreover, in order to successfully sell products and services abroad, firms need to market themselves abroad and establish relationships with their new customers.

Consequently, information and trust are essential ingredients in cross-border commercial activity and lack of these ingredients could deter trade. As many of the barriers that impeded trade historically have diminished in importance, it has been increasingly clear that "behind-the-border" barriers are growing increasingly more important. ${ }^{2}$

2 The OECD conducted a study on barriers and drivers to internationalization among small and medium sized firms, which clearly demonstrated the role of informal trade barriers in today's economy. Out of the five most serious impediments to internationalization ranked by small and medium sized firm, four are directly linked to lack of information, access to networks and inadequate trust in business relationships (OECD 2009). 
There are potentially two direct channels through which sport could encourage trade: ${ }^{3}$ First, countries that interact with each other through sport may increase their knowledge about each other. Engaging in sports can provide visibility opportunities for firms in the opposing team's market, and may spur the interest of both firms and consumers in the respective countries concerning the other team's country, its markets and its products. Hence, there might be a positive supply effect derived from firms' interest in a new, perhaps previously unknown or overlooked market, as well as a positive demand effect coming from consumers as the visibility of the opposing country's team has kindled the interest of the consumer.

Second, international trade is influenced by firms' ability to access business networks in other countries and the level of trust in these networks, as well as between sellers and buyers from different countries. Sport could form a catalyst for the formation of such networks and help to infuse trust into cross-country business relationships. ${ }^{4}$ In this regard, one example is the international tourism

3 These two channels are by no means distinct from each other. Rather, they can be mutually reinforcing. Increased visibility may foster trust and vice versa. Increased trust can provide enhanced possibilities for improved information. Also, we use the term "direct channels" since there might be a more general and long-term ("indirect channel") of influence, which is less relevant for the context of this study. One such channel is the influence of sport on overall relationships between countries (Spaaij 2012). The idea surrounding this channel was summarized by Jacques Rogge, the president of the International Olympic Committee, who stated: "Sport has the power to reach many people across the globe and, in essence, is a language understood by everyone. Sport also fosters understanding between individuals, facilitates dialogue between divergent communities and can contribute to breeding tolerance between nations." (Georgiadis and Syrigos 2009). There are historical examples that point to the role of sport in fostering peace: (1) In Ancient Greece, where wars were a common phenomenon, periods around the Olympic Games were relatively peaceful due to the ancient Greek tradition of "Ekecheira", the Olympic Truce. (2) The so-called Ping-Pong Diplomacy between the United States and China in the 1970s contributed to defrosting the political relations between the two countries during the Cold War. Nevertheless, because it is not logically convincing to assume that sport can improve overall political and diplomatic relations between countries in the short term, it is not likely that improved bilateral relations in general is a potential channel through which sport may increase trade. Hence, this is indeed an indirect channel through which effects should materialize after a long time, rendering this potential channel less relevant for this study, which is interested in analyzing the direct trade-sport link.

4 The idea that sport can build trust and mutual respect between individuals was expressed by one of the American players who played for the US in China during the era of Ping-Pong Diplomacy, he said: “The [Chinese] people are just like us. They are real, they're genuine, they got feelings. I made friends, I made genuine friends, you see. The country is similar to America, but still very different.” (United Press International 1971). 
which is often the result of sport events. Although the main driving force behind visits generated by, for instance, soccer matches is for fans to see their national teams win, such events may provide international visitors with an introduction to the opposing team's country, culture and customs. Presumably, because a soccer match seldom takes place for more than two hours, most sport related trips last longer than the actual sport event and therefore provide the foreign visitors with opportunity to explore more than the venue of the match.

Previous studies are ambiguous in their findings of the effects of hosting major sport events on macroeconomic outcomes, such as employment (e.g., Baade and Matheson 2001, 2004; Carlino and Coulson 2004; Hagn and Meannig 2008). This is interesting since policymakers often refer to positive employment effects as a way of justifying hosting a major sport event. Sterken (2006) analyzed the impact of organizing major sporting events on growth and found that organizing Summer Olympic Games stimulate per capita GDP, while FIFA World Cup does not. Nevertheless, Ahlert (2007) found a positive impact on Germany's GDP from hosting the World Cup. Rose and Spiegel (2011) examined countries that hosted the Olympic Games and found that hosting the Olympics is associated with up to 20 percent higher total foreign trade. The positive association is explained by, inter alia, that hosting the Olympics might signal a willingness of the hosting nation to increase economic openness.

In a recent study, Bayar and Schaur (2014) found that hosting the World Cup could raise exports by around 5 percent, temporarily. Further, Avsar and Unal (2014), using bilateral trade data for a panel of countries, found a positive trading effect of the World Cup.

This study hypothesizes that sport could encourage trade by increasing countries' visibility abroad (reducing information friction) and by encouraging the formation of social and business networks across different countries (reducing trust friction). Both theoretical and empirical work has provided support for the role of information and trust in international trade. Rauch (1999, 2001) discussed and provided evidence suggestive of the idea that networks matter for cross-border trade. Gould (1994), Head and Ries (1998), Rauch and Trindade (2002), Hatzigeorgiou (2010) and others have found a positive relationship between migration and trade, which has been interpreted as evidence of the importance of information and trust for trade costs. Specifically, migrants may help to facilitate the enforcement of contracts by providing inputs to the drafting of contracts and limiting opportunistic behavior via participation in crossnational networks (e. g., Greif 1989, 1993, 2012; Herander and Saavedra 2005). Additional relevant studies include Ahn, Khandelwal, and Wei (2011), who examined the role of intermediaries in trade and found that intermediaries facilitate for trade. Chaney (2011) used a firm productivity heterogeneity 
approach to develop a model in which a firm's ability to export to a foreign market is contingent upon having at least one contact in that market, thus also emphasizing that networks play a role for trade costs.

In regard to the premise that sport may increase trade by stimulating tourism, previous studies have also provided evidence demonstrating that travel can stimulate foreign trade because tourism contributes to lower trade costs through in-person meetings across national borders (Kulendran and Wilson 2000; Christea 2011).

When it comes to the role of sport as a catalyst for visibility and increased knowledge, this resembles the motivation for why most countries have foreign diplomatic missions that promote exports, why governments conduct trade delegations abroad, why there is often a minister in every cabinet responsible for trade promotion and why many countries have public export promotion agencies (EPAs). Part of the answer is this: visibility matters.

Governments want to attract visibility and provide good exposure to their companies in foreign markets. The rationale for the EPAs therefore goes beyond providing support services for firms, such as technical assistance and capacity building (e. g., Lederman, Olarreaga, and Payton 2010). This is clear since foreign diplomatic missions today, as well as the EPAs, are involved in creating visibility for their countries and their companies. This usually includes advertising, promotional events, trade fairs and so forth. Rose (2007) investigated the effect of foreign missions on bilateral trade and found a positive impact on trade of having foreign missions abroad. Similarly, Gil-Pareja, Llorca-Vivero, and Martínez-Serrano (2007) investigated the effect of embassies and consulates on tourism exports and also found a statistically significant and positive relationship. Ferguson and Forslid (2013) developed a Melitz-type model with heterogeneous firms, which was estimated using Swedish firm-level data. The results indicated that the effect of trade promotion via embassies was strongest for medium-sized firms.

Furthermore, Gil, Llorca, and Serrano (2008) investigated the role of Spanish export promotion offices abroad and the activities of Spain's official missions to other countries. They found that official missions have a positive and significant effect on Spain's foreign trade. Volpe Martincus and Carballo (2010) found similar evidence for Colombian firms, as did Creusen and Lejour (2013) for Dutch firms. Lederman, Olarreaga, and Payton (2010) looked at the average trade promoting effect of EPAs in 103 developed and developing countries and concluded that export promoting agencies, on average, have a significantly positive effect on exports, although the impact is characterized by diminishing returns.

In sum, previous research delivers two important lessons for this study. First, previous research gives support to the notion that the reduction of information and trust friction may facilitate for trade. Second, previous studies 
emphasize that visibility matters for exports, although the full effect is likely to also be attributed to other factors unrelated to exposure per se, such as technical trade assistance provided by many EPAs to firms that want to enter a foreign market. ${ }^{5}$

Assuming that sport can provide countries and firms with visibility and promote trust in cross-border business relationships, thus lowering trade costs between countries, to what extent is this likely to have an effect in reality? And why use soccer as an example of the potential impact of sport?

Soccer deserves particular focus in the context of studying the relationship between sport and international trade since it is the world's most popular sport. Most countries, regardless of geography, cultural orientation, or historic background, and irrespective of their level of development, have national soccer teams and participate in international tournaments. There are over 200 national teams and the game hosts some of the most watched sporting events worldwide. The game's global appeal has naturally made it the world's most watched TV sport. As shown in Table 1, the by far most watched TV sporting event of 2006

Table 1: Most watched TV sporting events.

\begin{tabular}{llrr}
\hline Sport & Event & $\begin{array}{r}\text { Average audience } \\
\text { (millions) }\end{array}$ & $\begin{array}{r}\text { Share of } \\
\text { total (\%) }\end{array}$ \\
\hline Soccer & FIFA World Cup Final & 260 & 41 \\
Football & Super Bowl & 98 & 16 \\
Soccer & UEFA Champions League Final & 86 & 14 \\
Formula One & FIA World Championship & 83 & 13 \\
NASCAR & Daytona 500 & 20 & 3 \\
Baseball & MLB World Series (Game 5) & 19 & 3 \\
Golf & US Masters' Final Fay & 17 & 3 \\
Tennis & Wimbeldon Lawn Championship & 17 & 3 \\
& Men's Singles Final & & \\
Basketball & NBA Finals (Game 6) & 17 & 3 \\
Cycling & Tour de France's Final Stage & 15 & 2 \\
\hline
\end{tabular}

Note: The numbers refer to the year 2006.

Source: Initiative, Futures Sport + Entertainment (2007).

5 There are also a few studies that have investigated visits conducted by heads of state and other government representatives with the aim of increasing exports. These studies are relevant to the study of trade and sport in the sense that athletes may act as representatives for their countries (and its firms and their products) in a similar way as do government officials. Nitsch (2007) found a positive impact of such activities for France, Germany and the US between the years 1948 and 2003, although Head and Ries (2010) did not find a similar positive impact of trade missions on Canadian exports. 
was the FIFA World Cup final, with an estimated 260 million viewers. ${ }^{6}$ The Super Bowl, which was the second most viewed event that year, attracted less than half of the total number of viewers of the FIFA World Cup final, and unlike soccer most of the viewers were found in one single country. The third most watched TV sporting event of 2006 was also a soccer match, the UEFA Champions League final, which attracted 86 million viewers. The final game in the 2010 FIFA World Cup, played between Spain and the Netherlands, attracted an estimated TV audience of 329 million viewers worldwide and was thus the most watched TV sporting event of that year.

Moreover, audience support of soccer is found in all demographics. In other words, soccer, more than any other sport, has vast exposure and impact worldwide, giving it the potential to have an impact on trade relationships among a large number of countries. ${ }^{7}$

If countries that are part of the worldwide interest and participation in soccer benefit from the positive contribution this sport makes to international trade, it stands to reason that countries that have little or no participation in international soccer are not likely to benefit from such positive impacts on trade. For example, the limited popularity of soccer in the US historically may have contributed to keeping information friction between the US and other countries intact, in particular towards countries that are geographically or culturally remote from America. However, as the game's popularity and appreciation in the US has increased - much thanks to the advancement by its national

\footnotetext{
6 The World Cup, governed by the International Football Association FIFA (Internationale de Football Association), is the biggest and most prestigious of all international soccer tournaments. The FIFA World Cup is organized over a four-year period with the final tournament is held every four years. More than 190 national teams enter the qualifying tournament, which takes place over a period of three years. The final tournament involves approximately 30 teams that compete for the world championship title for about a month. The Summer Olympics is another important international tournament. Notable regional tournaments include, among others, the UEFA European Football Championship, the Copa América, African Cup of Nations and the Asian Cup.

7 One possible drawback of focusing solely on soccer is the limit this might impose on the external validity of the results caused by the exceptionality of soccer as the world's most popular sport. Arguably, many other sports that get large audiences, such as American football or cricket, are mainly popular in a relatively small number of countries which are generally quite close already. In this case we would not expect to see much boost to trade from these countries playing each other. On the other hand, this does not say that these sports have intrinsically different capabilities in reducing information and trust friction relative to soccer. Rather, their expected inability to influence trade in this regard stems from a lack of global recognition, which is not set in stone and furthermore is a fundamentally different assertion than soccer per se not being a generally applicable example of the potential impact of sport.
} 
team in recent international soccer tournaments - a valid question is whether this has helped to reduce information frictions between the US and other markets by increasing the knowledge about other countries among Americans and their firms.

Slovenia is a small European country roughly the same size as New Jersey. Its total population amounts to a mere two million inhabitants. Nevertheless, the match between the US national soccer team and Slovenia became, at the time of its TV broadcast, the most-watched soccer game in the history of ESPN networks. Close to four million households watched this match on TV (Gorman 2010). If most of the millions of Americans who watched the US team play against Slovenia had little or no prior knowledge of Slovenia's existence, they certainly knew of Slovenia by the time the match had ended.

A similar argument can be made about Ghana. It is a small country in West Africa, roughly the size of Oregon. Although Ghana has a considerably bigger population than Slovenia, the fact that the important Stage 2 match in the 2010 World Cup between the US and Ghana was watched by the largest TV audience for a single soccer match in US television history may have contributed considerably to the knowledge about Ghana among the approximately 20 million Americans who watched this match.

In these cases, the participation of the US national soccer team in the World Cup had the potential of adding knowledge about several geographically and culturally remote countries to a considerable number of American households and firms. By playing key televised soccer matches against the US, countries such as Slovenia and Ghana attracted the attention of millions of Americans in a way that likely no conventional marketing approach could have matched. Consequently, information barriers between the US and the countries its national soccer team played were possibly lowered, which in turn may have spurred foreign trade between the US and those countries.

Figures 1 and 2 plot US exports and imports to and from Ghana as well as to and from Slovenia respectively over time, with the red vertical lines indicating the time of a World Cup soccer match being played between the countries. Notably, both exports and imports to and from Ghana were at stable levels for many years. However, exports to Ghana started to increase substantially after 2006, the same year the US national team played Ghana in the World Cup. Imports from Ghana did not increase noticeably until 2010, which interestingly was the second time the US played Ghana in the World Cup. This time it was as a result of the US having won its group for the first time in the history of the modern games, which in itself attracted much interest in the US. Before winning the group, the US had also played Slovenia and as demonstrated in the figure, exports to Slovenia experienced a spike after that same year. 


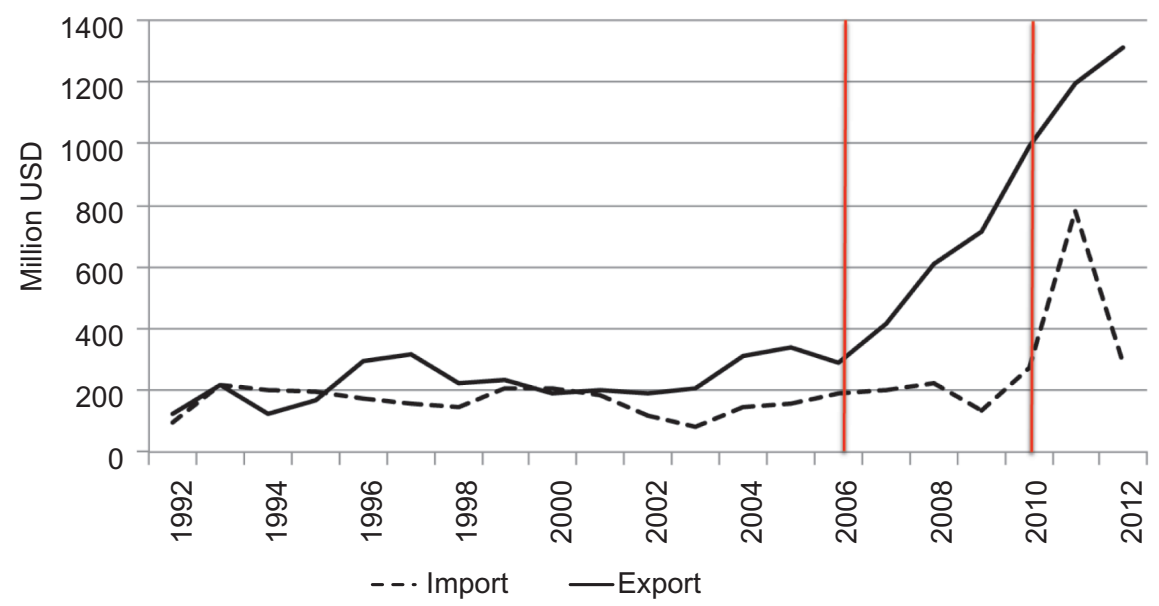

Figure 1: US trade with Ghana 1992-2012.

Source: US Department of Commerce, Bureau of the Census, Foreign Trade Division.

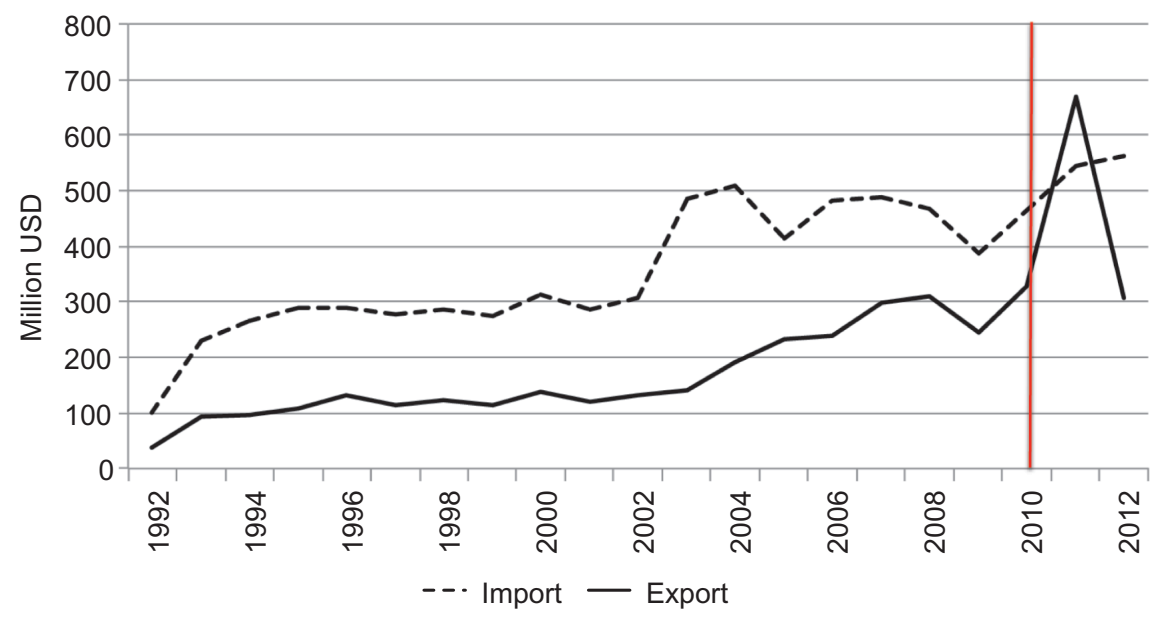

Figure 2: US trade with Slovenia 1992-2012.

Source: US Department of Commerce, Bureau of the Census, Foreign Trade Division.

The World Cup matches played between the US and Slovenia and Ghana are interesting for two at least a couple of reasons. The matches received exceptional attention in the US and the matches involved countries that are remote to the US and never before - at least to our knowledge - have experienced a similar level of 
focus in the US. These anecdotal examples, together with the ideas outlined in the conceptual framework, motivate a more systematic exploration of the potential relationship between trade and sport.

\section{Empirical Strategy}

In the context of this study, as previously discussed, it is assumed that information and trust friction as well as lack of visibility in international markets constitute barriers to trade. Sport can be a tool for lowering information frictions between countries, for promoting trust between sellers and buyers across nations and for countries to achieve visibility in foreign markets. As explained, this study focuses on soccer and thus includes a control variable for the number of matches played between the national soccer teams of country $i$ and country $j$. The baseline equation to be estimated in this study is

$$
\ln x_{i j t}=\alpha+\beta_{1} s_{i j t}+\sum_{k} \gamma_{k} z_{k i j}+\beta_{2} R T A_{i j t}+\beta_{3} c u r_{i j t}+I_{i t}+I_{j t}+I_{i}+I_{j}+I_{t}+\varepsilon_{i j t},
$$

where $x_{i j t}$ represents logarithmic bilateral exports from $i$ to $j$ at time $t$. The number of soccer matches played between countries $i$ and $j$ during year $t$ is represented by $s_{i j t}$. A set of conventional gravity explanatory variables control for various bilateral characteristics such as distance, adjacency and shared language. Two covariates, $R T A_{i j t}$ and $\operatorname{cur}_{i j t}$, account for countries being member of the same regional free trade agreement or the same currency union. $I_{i t}$ and $I_{j t}$ are exporter and importer time-varying fixed effects, included to control for countries' multilateral resistance with respect to the rest of the world over time. $I_{i}$ and $I_{j}$ are exporter and importer fixed effects that control for countryspecific characteristics. $I_{t}$ are time fixed effects and control for year-specific shocks. $\varepsilon_{i j t}$ is an idiosyncratic error term.

There are obvious concerns over endogeneity within in this context. We take several measures to address selection and other potential problems. As will be explained, we implement a sample selection model, and it should be emphasized that the inclusion of fixed effects control for countries' income levels. We address determinants of the probability that countries face each other in a soccer game through controls for being part of the same geographic region and for belonging to the same RTA.

Importantly, we utilize the exogenous nature of soccer matches. Many of the soccer matches, especially those associated with regional and international tournaments, are products of draw procedures and thus randomly determined. 
This implies that countries themselves cannot have an impact on the choice of opposing teams. Although draw procedures may vary across different tournaments, the procedures to determine which countries national teams play each other are characterized by a high degree of randomness. The FIFA World Cup, for instance, has special draw procedures that are adopted for both of the preliminary competition and the final competition. ${ }^{8}$

Via the preliminary competition and elimination process, approximately 200 of the world's national soccer teams are reduced to 32. Qualifying tournaments are held within the different continental zones - Africa, Asia, Europe, Caribbean and Central and North America, South America, Oceania - but individual matches are drawn on a random basis, ensuring that no specific country can influence which other national team its own team shall play (e. g., FIFA 2010). ${ }^{9}$

In other words, nations are unable to affect the extent to which their national teams focus on playing national soccer teams from countries with which they have strong ties, whether they are based on politics, trade or culture. By the same token, nations cannot refuse - unless they are willing to withdraw from the tournament to play teams from countries with which they have poor relations. Several historical matches support this notion that countries are constrained by the rules of international sport organizations in influencing what matches teams will play, when they will be played and where matches will take place. ${ }^{10}$

While countries may agree to play so-called friendly matches that are not randomly determined per definition, the purpose of such friendly matches is generally to prepare teams and players for matches that will be played in tournaments. Therefore, it is not completely convincing to think that national

8 In many ways these draw procedures are identical to a lottery draw. For the World Cup and other international tournaments, representatives from the relevant soccer association literally draw tickets from a bowl containing all the teams. This is usually done in public and broadcasted worldwide since the outcome can be important for countries' chances to succeed in the tournament.

9 Since countries that belong to the same geographic region have a higher probability to play each other during qualifying rounds of international tournaments like the FIFA World Cup, it is important to control for whether two countries belong to the same region in the world, which the model estimated by this study indeed does.

10 For example, the diplomatically sensitive match between South Korea and North Korea during the qualification tournament to the World Cup 2010 in South Africa is one instance where sport trumped politics, and the 1969 World Cup qualifier between El Salvador and Honduras, which even provided the starting shot to a brief war, is another. Furthermore, after decades of tense relations between Armenia and Turkey, these two neighbors' national soccer teams were drawn to meet each other in a World Cup qualifying game in 2008. The match was played despite considerable political and diplomatic tension. 
soccer teams systematically pick friendly matches in ways that would render soccer matches endogenous with respect to trade. In our view, there should be a rather low risk of friendly matches being systematically played between countries with strong preexisting trade relationships. Rather, when it is possible to influence the choice of opposing team, national teams would most likely want to play matches that will provide the best training and for maximizing chances of performing well in real tournaments. Still, we recognize that friendly matches are not permeated by the same randomness as non-friendly matches are. Therefore, the risk of endogeneity in this regard cannot be ignored and we address the issue by exploiting information which allow us to consider only such matches that are exogenous with respect to trade.

Trade data are taken from the Base Pour l'Analyse du Commerce International (BACI) database, which is based on the UN Comtrade database (Gaulier and Zignago 2010). Bilateral trade values in BACI are weighted across trading partners to achieve asymmetry and consistent trade flows. The increased coverage to more than 200 countries and 5,000 products, available over the period 1980-2004, is achieved by mirroring rows. The geographical and historic indicators come from the Centre d'Etudes Prospective et d'Informations Internationales (CEPII).

Given the availability of data, the full sample to be used in this study covers 209 countries and the six years from 1995 to 2001. The countries included in the dataset are listed in Table 7. The key variable, the number of soccer matches played between country pairs, comes from the International Federation of Association Football (FIFA) and the archive of the Rec.Sport.Soccer Statistics Foundation (RSSSF). Data cover a total of 4,860 soccer matches. Additional information on the variables included in the dataset is provided in the appendix. Descriptive statistics on the main variables are provided in the appendix.

\section{Results}

The benchmark results are presented in Table 2, where the standard gravity coefficients all have the expected sign. ${ }^{11}$ The results suggested that soccer does

11 The benchmark results are estimated using fixed effects estimation, a technique which assumes that the unobserved heterogeneity we wish to account for does not vary over time. An alternative approach of estimating our augmented gravity equation for panel data would have been to use the random effects model (e. g., Egger 2002; Carrère 2006). We abstain from this, however, since this approach would force us to assume that multilateral resistance is normally distributed, which is perhaps an even more restrictive assumption. 
Table 2: OLS fixed-effects estimation results.

\begin{tabular}{|c|c|c|c|c|}
\hline & $\begin{array}{r}\text { (1) } \\
\text { Aggregate } \\
\text { exports }\end{array}$ & $\begin{array}{r}(2) \\
\text { Differentiated } \\
\text { goods }\end{array}$ & $\begin{array}{r}(3) \\
\text { Homogeneous } \\
\text { goods }\end{array}$ & $\begin{array}{r}(4) \\
\text { Friendly matches } \\
\text { excluded }\end{array}$ \\
\hline Soccer matches & $\begin{array}{l}0.172^{\star \star \star} \\
(0.024)\end{array}$ & $\begin{array}{l}0.194^{\star \star \star} \\
(0.023)\end{array}$ & $\begin{array}{l}0.165^{\star \star \star} \\
(0.025)\end{array}$ & $\begin{array}{l}0.135^{\star \star \star} \\
(0.028)\end{array}$ \\
\hline Distance & $\begin{array}{l}-1.194^{\star \star \star} \\
(0.026)\end{array}$ & $\begin{array}{l}-1.197^{\star \star \star} \\
(0.024)\end{array}$ & $\begin{array}{l}-1.241^{\star \star \star *} \\
(0.029)\end{array}$ & $\begin{array}{l}-1.199^{\star \star \star} \\
(0.026)\end{array}$ \\
\hline Adjacency & $\begin{array}{r}0.844^{\star \star \star} \\
(0.102)\end{array}$ & $\begin{array}{l}0.909^{\star \star *} \\
(0.098)\end{array}$ & $\begin{array}{l}0.823^{\star \star *} \\
(0.100)\end{array}$ & $\begin{array}{l}0.854^{\star \star \star \star} \\
(0.102)\end{array}$ \\
\hline $\begin{array}{l}\text { Common } \\
\text { language }\end{array}$ & $\begin{array}{l}0.675^{\star \star \star} \\
(0.040)\end{array}$ & $\begin{array}{l}0.730^{\star \star \star} \\
(0.039)\end{array}$ & $\begin{array}{l}0.460^{\star \star \star} \\
(0.046)\end{array}$ & $\begin{array}{l}0.679^{\star \star \star} \\
(0.040)\end{array}$ \\
\hline $\begin{array}{l}\text { Colonial } \\
\quad \text { relationship }\end{array}$ & $\begin{array}{l}1.104^{\star \star \star} \\
(0.097)\end{array}$ & $\begin{array}{l}0.984^{\star \star \star} \\
(0.094)\end{array}$ & $\begin{array}{l}1.138^{\star \star \star} \\
(0.091)\end{array}$ & $\begin{array}{l}1.098^{\star \star \star} \\
(0.097)\end{array}$ \\
\hline Same region & $\begin{array}{l}0.396^{\star \star \star} \\
(0.049)\end{array}$ & $\begin{array}{l}0.425^{\star \star \star *} \\
(0.045)\end{array}$ & $\begin{array}{l}0.434^{\star \star \star} \\
(0.052)\end{array}$ & $\begin{array}{l}0.399^{\star \star \star} \\
(0.049)\end{array}$ \\
\hline RTA & $\begin{array}{l}0.501^{\star \star \star *} \\
(0.037)\end{array}$ & $\begin{array}{l}0.491^{\star \star \star} \\
(0.035)\end{array}$ & $\begin{array}{l}0.426^{\star \star \star} \\
(0.040)\end{array}$ & $\begin{array}{l}0.504^{\star \star \star} \\
(0.037)\end{array}$ \\
\hline Currency union & $\begin{array}{l}0.436^{\star \star \star} \\
(0.117)\end{array}$ & $\begin{array}{l}0.640^{\star \star \star} \\
(0.107)\end{array}$ & $\begin{array}{l}0.369^{\star \star \star} \\
(0.117)\end{array}$ & $\begin{array}{l}0.441^{\star \star \star} \\
(0.117)\end{array}$ \\
\hline Observations & 144,236 & 130,931 & 117,537 & 144,236 \\
\hline Adjusted $R^{2}$ & 0.734 & 0.763 & 0.647 & 0.734 \\
\hline
\end{tabular}

Exports (logarithm) is the dependent variable throughout. Robust standard errors in parentheses (clustering by country pairs). Importer and exporter specific fixed effects, year indicators as well as year-importer and year-exporter fixed effects are included in all regressions.

${ }^{\star} p<0.10,{ }^{\star *} p<0.05,{ }^{* \star *} p<0.01$

have a positive and statistically significant link with exports. As shown in the first column, a soccer match played between two countries national teams is associated with 19 percent higher export. ${ }^{12}$

To test the strength of the hypothesis that the positive soccer effect on trade operates through the information and trust channel, trade data are divided into three categories: differentiated goods, referenced-priced goods and homogeneous goods. The latter two groups are assumed here to be homogeneous and the categorization follows the "conservative" approach used by Rauch and Casella (2002). Regressions are then performed separately for differentiated and homogeneous goods. The soccer effect on exports is expected to be larger for differentiated goods than for

12 Since the predictor soccer variable is not log transformed the result is the exponentiated coefficient $\mathrm{e}^{0.172}=1.19=19 \%$. 
homogeneous goods if the hypothesis that sport decrease trade costs is correct, since trade in differentiated goods is more sensitive to information and trust frictions than is the case for homogeneous goods.

These results presented in column 2 and 3 are suggestive of the hypothesis that sport influence trade primarily via the information and network channel. The trade-sport link is suggested to be especially important with respect to exports of differentiated goods, where soccer is estimated to be associated with 21 percent higher export.

Countries may agree to play so-called friendly matches against each other, in which they can potentially impact the choice of the opposing team. As discussed, the main purpose of such friendly matches is to prepare teams and players for matches that will be played in tournaments. Admittedly, however, friendly matches are not intrinsically random in the same sense as tournament matches are. In order to eliminate the possibility of endogeneity in this regard, we run a regression based on data for soccer matches that by definition are exogenous with respect to trade, that is for non-friendly matches exclusively.

The results presented in column 4 demonstrate that previous results remain intact even when friendly soccer matches are dropped from the data. Although the point estimate of the soccer variable is smaller than for the regression with all soccer matches, the coefficient is still highly significant and positive. The estimated results suggested that a randomly drawn soccer match played between two countries' national soccer teams is associated with 15 percent higher exports on average.

Although several trade-theoretical studies have contributed to the model's conceptual foundation in recent year (e.g., Anderson 1979; Helpman and Krugman 1985; Bergstrand 1989; Deardorff 1998; Eaton and Kortum 2002; Anderson and van Wincoop 2003), there have been some outstanding issues regarding estimation. A weakness of the log-linear form of the gravity equation is that it does not take into account zero trade flows. Because the logarithm of zero is undefined, straightforward OLS estimation of the log-linear form of the gravity model will ignore all observations with zero or missing trade. This approach, though it implies a risk of biased estimates in cases where zeros are not randomly distributed, has been adopted by numerous empirical trade studies. However, with respect to correct specification and estimation of the gravity model, Eaton and Tamura (1994), Egger (2000), Limão and Venables (2001), Egger and Pfaffermayr (2003), Santos Silva and Tenreyro (2006), Helpman, Melitz, and Rubinstein (2008), Burger, van Oort, and Linders (2009), Anderson (2011), Westerlund and Wilhelmsson (2011) and others provided insights into many econometric aspects surrounding the gravity model, such as methods for addressing zero or missing trade. 
Since our data contain a considerable number of zero trade flows, and because we do not know whether or not the zeros are randomly distributed, our econometric specification is estimated using an alternative estimator. While the Tobit estimator and the Poisson (Pseudo-)Maximimum Likelihood (PPML) estimator can be applied to address the issue of log-linear transformation of zeros, neither estimator account for selection in the data generating process. ${ }^{13}$ Therefore, to account for sample selection, our model is estimated using a Heckman (1979) sample selection model, which combines a first stage Probit model (selection equation) and a second stage OLS regression (outcome), using common religion as the exclusion restriction in the spirit of Helpman, Melitz, and Rubinstein (2008). ${ }^{14}$

The results presented in Table 3 demonstrate that the significant and positive estimate of soccer matches is robust to accounting for selection. The estimated

13 These estimators are associated with additional problems that lead us to mainly apply them for robustness tests. But even for this purpose, their results should be interpreted with caution. The Poisson model as proposed by Santos Silva and Tenreyro (2006) and others is quite vulnerable to certain features in trade data. Although the Poisson Pseudo-Maximum Likelihood estimator solves the heteroscedasticity-bias problem, it can result in severely biased estimates when zero trade values are frequent. Approximately 52 percent of the observations in our sample are zeros and tests show that our data are likely to be characterized by selection. Therefore, we think the PPML estimator performs poorly compared to the Heckman selection model.

14 The purpose of the exclusion variable is to identify relevant parameters in the selection and outcome equation, where the exclusion variable should influence mainly trade propensity and not trade levels. There are several examples of different exclusion variables in the literature and common religion is by no means a perfect identifier for the trade decision process. We assert, however, that relative to other exclusion variables that have appeared in the literature - for which there is available data - such as common language, common religion is the preferred option. For other potentially better exclusion variables, such as business regulations that may mainly influence trade entry rather than levels of trade, data is not available for the 1995-2001 period and for the large number of countries included in this study. World Bank Doing Business data, for instance, go back no further than 2004. Although selection estimation is the preferred approach, it was not possible to run these regressions with all of the fixed effects (approximately 3,000) specified in the main model. The computer we used was equipped with a powerful quad-core Intel Core i7 (with Turbo Boost up to $3.3 \mathrm{GHz}$ ) processor, 8 GB DDR3 memory and the latest and fastest version of Stata/MP for multicore/multiprocessor computers. Yet, it was not possible to estimate the full model using the Heckman or Poisson estimator. As a compromise, we included "quasi-controls" for time-variant multilateral trade resistances in the form of region-reporter-year and region-partner-year indicators. The corresponding OLS estimates using these controls are provided in the appendix (the estimates are similar to those of the full model). 


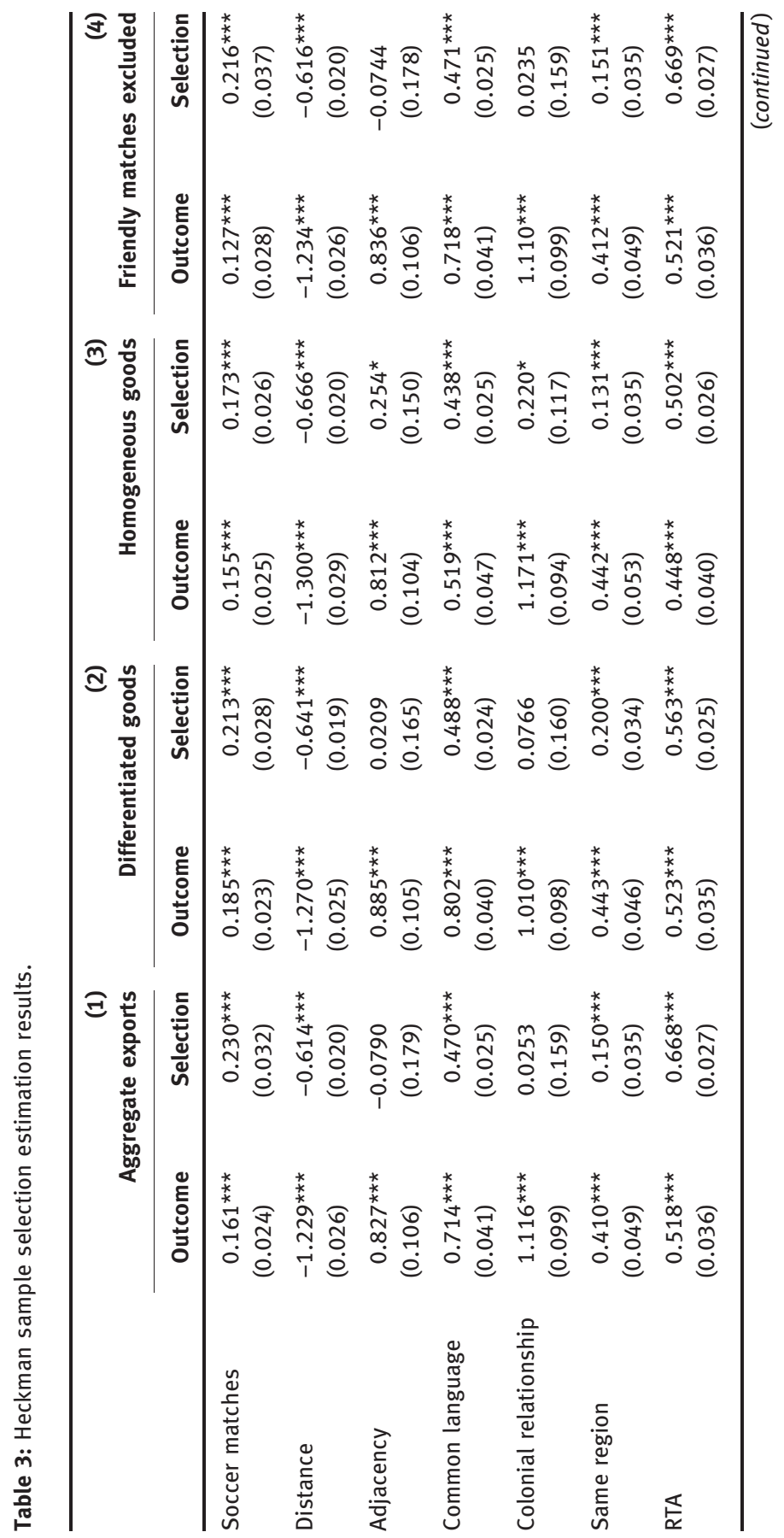




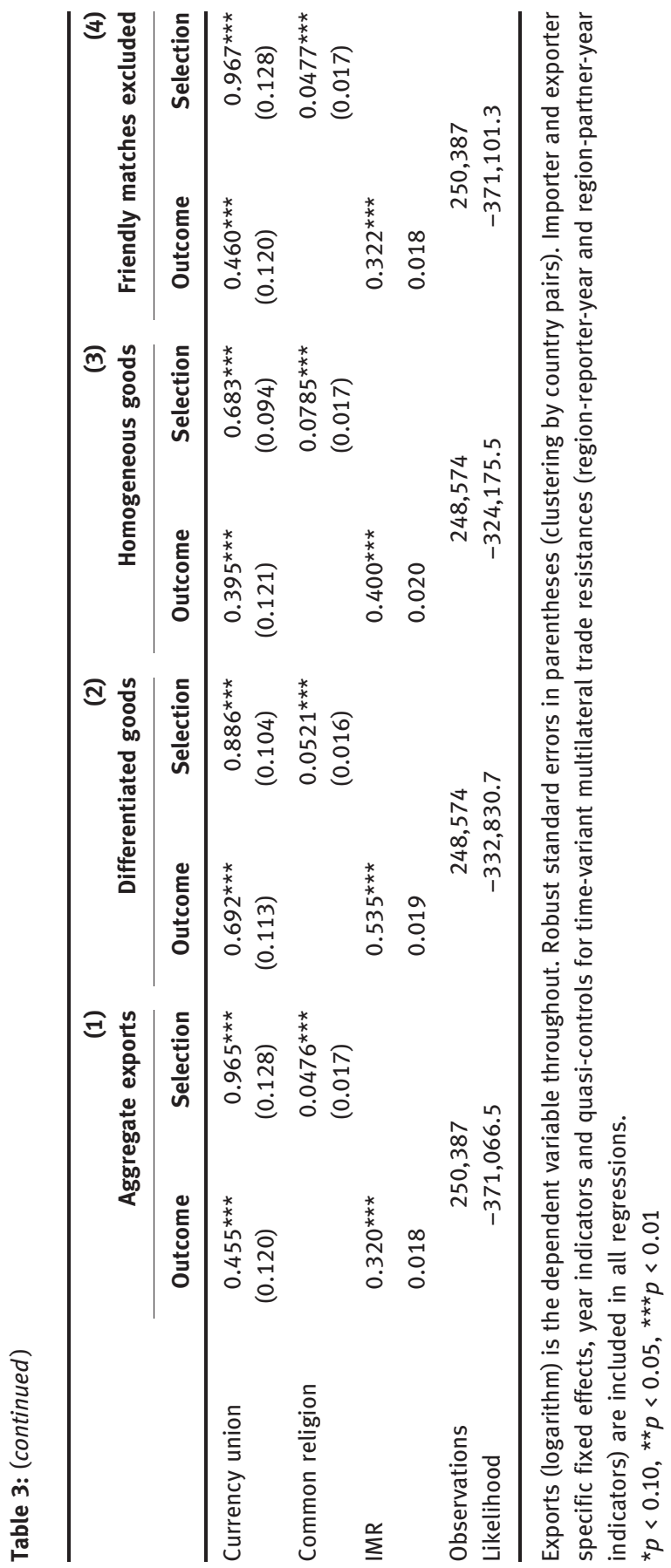


link is stronger for differentiated than for homogeneous goods, which are presumed to be particularly harmful for trade in differentiated goods.

In column 4, results are provided for the model estimated using only nonfriendly matches. This result is especially interesting since it is based on matches that are with even less doubt are exogenous.

The exogenous nature of the data, together with an estimation approach, which addresses selection, may suggested that the estimation results are indicative of a causal influence of countries' engagement in sporting activities on their bilateral trade. In this sense, facing each other in soccer could have the potential to raise exports by up to 14 percent on average. This implies a substantial economic impact of sport on bilateral trade, but should not be considered unreasonably large. The fact that most countries have played only a few matches against each other during the time period covered, together with the fact that a considerable number of countries playing each other have rather modest bilateral trade, a 14 percent estimated increase, on average, constitute a reasonable estimated trading effect. ${ }^{15}$ The size of the estimated impact is furthermore in line with previous studies. For instance, Rose and Spiegel (2011) found that trade is around 30 percent higher for countries that have hosted the Olympics, and Avsar and Unal (2014) estimated that trade is about 18-20 percent higher for host-participant combinations when compared to other country pairs in the years of the World Cup.

Table 4 provides results of addition robustness checks and what this table shows is that the main findings are robust to several tests. In the first column, the model is estimated using OLS after a one has been added to the dependent variable before taking logs in order to avoid truncation. The second column provides results based on the Tobit estimator for non-friendly matches and differentiated goods. Although we think the Tobit estimator performs poorly compared to the preferred approach, the coefficient is significant and positive.

The following columns are estimated using the Heckman sample selection approach. It could be the case that the number of times the national teams have played each other is irrelevant for the trade-sport link in the sense that the important thing may be that countries engage in sports whatsoever. In the third column, results are therefore shown for a model using a binary indicator to control for soccer matches (unity if countries played each other, zero otherwise)

15 As a robustness test we regress trade on the total number of matches, which did not alter the main results (see Table 4). 


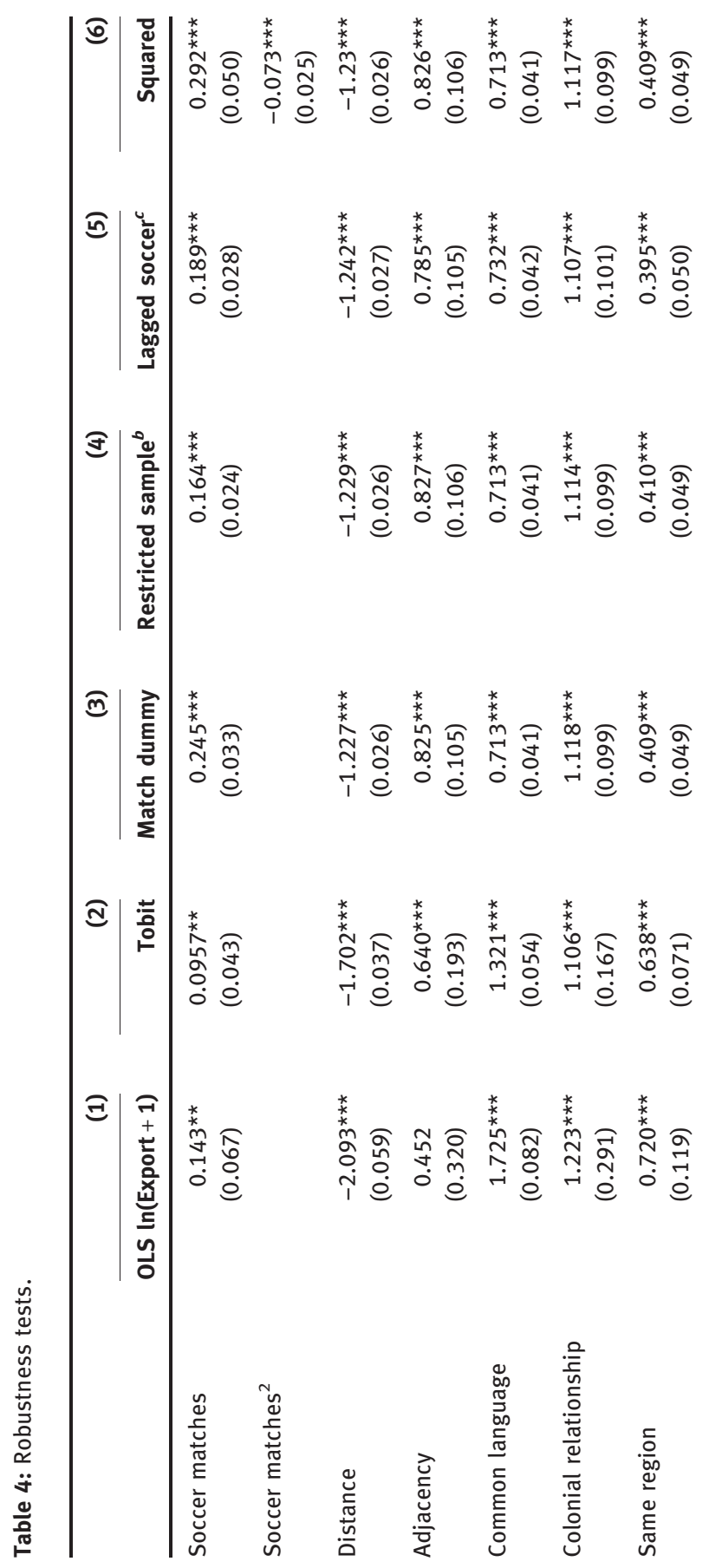




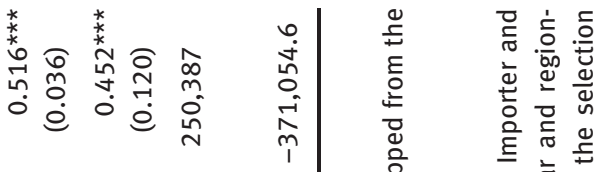

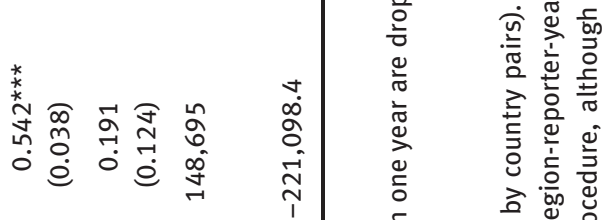

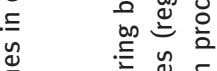

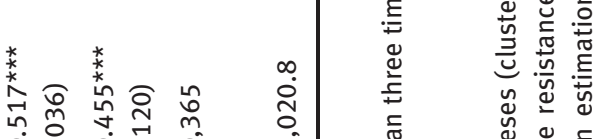

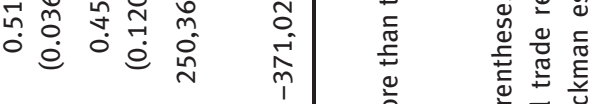

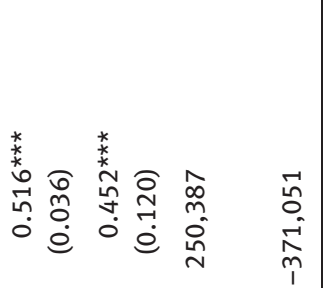

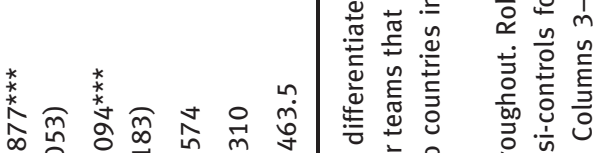

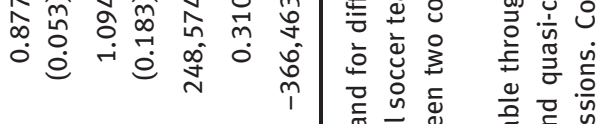

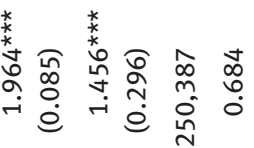

$$
\begin{aligned}
& \text { ป ठ }
\end{aligned}
$$

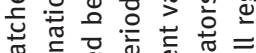

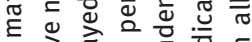

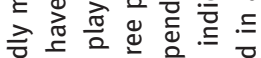

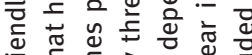

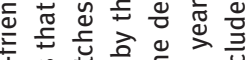

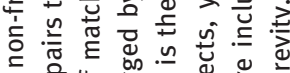

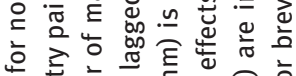

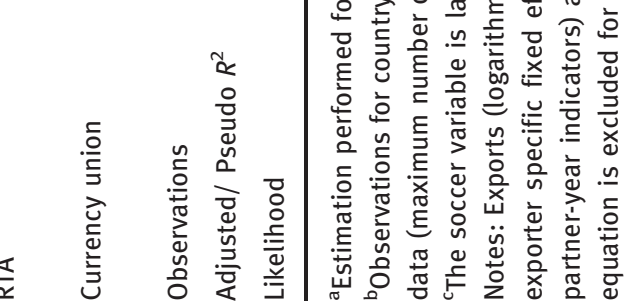


instead of the total number of matches played between two countries in one year. Consistent with this idea the estimated impact of the prevalence of any soccer match between two countries is similar to the result using the total number of matches.

In the fourth column, observations are dropped for countries that played each other more than three times during one year to ensure that these "outliers" are not driving the main results. The fifth column provides results from lagging the soccer variable by three periods and the main result is intact to this exercise. ${ }^{16}$ In the last column, we add a squared term of the soccer variable to account for possible diminishing returns of soccer matches. The marginal estimated impact considering the squared term was 0.22 and significant at the 1 percent level, which emphasize that although the trade-sport relationship is characterized by diminishing returns, the overall impact is statistically significant and positive.

\section{Conclusions}

International trade costs remain large, despite successive waves of trade liberalization and technological advances in transport, information and communication technology. Distance discourages trade as much as it did 60 years ago (Disdier and Head 2008). At the same time, as conventional barriers to trade have diminished in importance, informal barriers have become relatively more important (Anderson and van Wincoop 2004). Information costs and lack of trust account for a considerable share of trade costs and may be expected to rise as trade in heterogeneous products and across more dissimilar countries becomes more common and as the value of time increases.

In this context, it is valid to ask whether sport - a phenomenon that is believed to contribute to bringing countries and people closer together - has a role to play in lowering trade costs, such as information and trust friction, and thus spur international trade.

16 A lagged variable approach contains several challenges, including increased data requirements. This table provides regression result with lags of three periods, which seems as a reasonable number of lagged periods given the available data. However, the results are also robust to the inclusion of lags of different periods. The full results are provided in Table 9. 
Soccer is the world's most popular sport. It has arguably 3.5 billion fans worldwide, and more or less all nations of the world have national soccer teams. Soccer has more television viewers and draws larger audiences than any other sport. This study has thus used soccer as an example of the potential impact of sport in general. We utilized the fact that many soccer matches between countries' national teams are the result of a random drawing procedure, which is exogenous to trade. For this quasi-experimental data, which covered approximately 4,800 soccer matches played between 209 countries during the period 1995 through 2001, we estimated an augmented gravity model framework to analyze the potential influence of soccer on trade. This study also tested the validity of the hypothesized underlying impact channel by analyzing the impact on trade for goods that are likely to have different elasticity with respect to information and trust friction.

The pattern of results revealed by this study suggests that sport - especially globally popular sports such as soccer - can help to encourage trade between countries. Not only are the findings statistically significant and indicative of a causal influence, the results are also economically significant. Therefore, sports can help to increase foreign trade and promote global economic integration.

As for avenues for future research, it would be interesting to see whether similar statistically significant and positive estimations can be found with respect to sports other than soccer. Although we argued that soccer is a good example of the potential impact of sport, this would strengthen the external validity of the findings provided by this study.

Nevertheless, the findings of this study could still have interesting implications for policy in that they emphasize the potential for governments that seek to promote their exports by enhancing their visibility abroad and lowering the information hurdles facing their firms with respect to foreign markets. Firms have long understood the capacity for visibility in association with sport events, which the vast sums firms pay for marketing in sports bear witness to. As this study has demonstrated, sport may not only be beneficial for individual firms that market themselves on jerseys and in arenas, but to entire countries as well. Governments may therefore want to take advantage of the role that sport can play within the context of trade promotion policy. In specific, governments can encourage sporting activities together with countries with which they want to enhance their trade.

Acknowledgement: We are thankful for useful comments and suggestions from Joakim Gullstrand, Robert M. Stern, Ben Shepherd, Ross Wilson and Dean Yang. The usual caveats apply. 


\section{References}

Ahlert, G. 2007. "Hosting the FIFA World Cup Germany 2006: Macroeconomic and Regional Economic Impacts." Journal of Convention \& Event Tourism 8 (2):57-78.

Ahn, J., A. K. Khandelwal, and S. J. Wei. 2011. "The Role of Intermediaries in Facilitating Trade." Journal of International Economics 84 (1):73-85.

Anderson, J. 1979. "A Theoretical Foundation for the Gravity Equation." American Economic Review 69 (1):106-16.

Anderson, J. 2011. "The Gravity Model.” Annual Review of Economics 3 (1):133-60.

Anderson, J., and D. Marcouiller. 2002. "Insecurity and the Pattern of Trade: An Empirical Investigation." Review of Economics and Statistics 84 (2):342-52.

Anderson, J., and E. van Wincoop. 2003. "Gravity with Gravitas: A Solution to the Border Puzzle." American Economic Review 93 (1):170-92.

Anderson, J., and E. van Wincoop. 2004. "Trade Costs." Journal of Economic Literature 42 (3):691-751.

Avsar, V., and U. Unal. 2014. "Trading Effects of the FIFA World Cup." Kyklos 67 (3):315-29.

Baade, R. A., and V. A. Matheson. 2001. "Home Run or Wild Pitch? Assessing the Economic Impact of Major League Baseball's All-Star Game." Journal of Sports Economics

2 (4):307-27.

Baade, R. A., and V. A. Matheson. 2004. "The Quest for the Cup: Assessing the Economic Impact of the World Cup." Regional Studies 38 (4):343-54.

Bayar, O., and G. Schaur. 2014. "The Impact of Visibility on Trade: Evidence from the World Cup." Review of International Economics 22 (4):759-782.

Bergstrand, J. 1989. "The Generalized Gravity Equation, Monopolistic Competition, and the Factor-Proportions Theory in International Trade." The Review of Economics and Statistics 71 (1):143-53.

Bernard, A., S. Redding, and P. Schott. 2007. "Comparative Advantage and Heterogeneous Firms." Review of Economic Studies 74 (1):31-66.

Burger, M., F. van Oort, and G.-J. Linders. 2009. "On the Specification of the Gravity Model of Trade: Zeros, Excess Zeros and Zero-Inflated Estimation.” Spatial Economic Analysis 4 (2):167-90.

Carlino, G., and N. E. Coulson. 2004. "Compensating Differentials and the Social Benefits of the NFL." Journal of Urban Economics 56 (1):25-50.

Carrère, C. 2006. "Revisiting the Effects of Regional Trade Agreements on Trade Flows with Proper Specification of the Gravity Model.” European Economic Review 50 (2):223-47.

Casella, A., and J. E. Rauch. 2002. "Anonymous Market and Group Ties in International Trade." Journal of International Economics 58 (1):19-47.

Chaney, T. 2011. "The Network Structure of International Trade. National Bureau of Economic Research.” Working Paper No. 16753.

Creusen, H., and A. Lejour. 2013. "Market Entry and Economic Diplomacy." Applied Economics Letters 20 (5):504-7.

Cristea, A. D. 2011. "Buyer-Seller Relationships in International Trade: Evidence from US States' Exports and Business-Class Travel.” Journal of International Economics 84 (2):207-20.

Deardorff, A. 1998. "Determinants of Bilateral Trade: Does Gravity Work in a Neoclassical World?" In The Regionalization of the World Economy, edited by J. Frankel. Chicago: Chicago University Press. 
Disdier, A. C., and K. Head. 2008. "The Puzzling Persistence of the Distance Effect on Bilateral Trade." The Review of Economics and Statistics 90 (1):37-48.

Eaton, J., and S. Kortum. 2002. "Technology, Geography, and Trade." Econometrica 70 (5):1741-79. Eaton, J., and A. Tamura. 1994. "Bilateralism and Regionalism in Japanese and US Trade and Direct Foreign Investment Patterns." Journal of the Japanese and International Economies 8 (4):478-510.

Egger, P. 2000. "A Note on the Proper Econometric Specification of the Gravity Equation.” Economics Letters 66 (1):25-31.

Egger, P. 2002. "An Econometric View on the Estimation of Gravity Models and the Calculation of Trade Potentials." The World Economy 25 (2):297-312.

Egger, P., and A. Lassmann. 2012. "The Language Effect in International Trade: A Meta-Analysis.” Economics Letters 116 (2):221-4.

Egger, P., and M. Pfaffermayr. 2003. "The Proper Panel Econometric Specification of the Gravity Equation: A Three-Way Model with Bilateral Interaction Effects.” Empirical Economics 28 (3):571-80.

Elsass, P., and J. Veiga. 1994. "Acculturation in Acquired Organizations: A Force-Field Perspective." Human Relations 47 (4):431-431.

Ferguson, S., and R. Forslid. 2013. “Do Embassies Promote Exports?” Mimeo.

FIFA. 2010. Regulations - 2010 FIFA World Cup. Zurich: Fédération Internationale de Football Association.

Gaulier, G., and S. Zignago. 2010. "BACI: International Trade Database at the Product-Level (the 1994-2007 Version).” Mimeo.

Georgiadis, K., and A. Syrigos. 2009. "Introduction." In Olympic Truce - Sport as a Platform for Peace, edited by K. Georgiadis and A. Syrigos. Athens: The International Olympic Truce Centre.

Gil, S., R. Llorca, and J. A. M. Serrano. 2008. "Measuring the Impact of Regional Export Promotion: The Spanish Case." Papers in Regional Science 87 (1):139-46.

Gil-Pareja, S., R. Llorca-Vivero, and J. A. Martínez-Serrano. 2007. "The Impact of Embassies and Consulates on Tourism." Tourism Management 28 (2):355-60.

Glick, R., and A. K. Rose. 2002. "Does a Currency Union Affect Trade? The Time-Series Evidence." European Economic Review 46 (6):1125-51.

Gorman, B. 2010. “U.S. - Slovenia FIFA World Cup Match is ESPN's Most-Watched Soccer Telecast." TV by Numbers. Accessed March 2012. http://tvbythenumbers.zap2it.com/2010/06/19/u-sslovenia-fifa-world-cup-match-is-espns-most-watched-soccer-telecast/54715/.

Gould, D. 1994. "Immigrant Links to the Home Country: Empirical Implications for US Bilateral Trade Flows." Review of Economics and Statistics 76 (2):302-16.

Greif, A. 1989. "Reputation and Coalitions in Medieval Trade: Evidence on the Maghribi Traders." The Journal of Economic History 49 (04):857-82.

Greif, A. 1993. "Contract Enforceability and Economic Institutions in Early Trade: The Maghribi Traders' Coalition.” American Economic Review 83 (3):525-48.

Greif, A. 2012. "The Maghribi Traders: A Reappraisal?." The Economic History Review 65 (2):445-69.

Guiso, L., P. Sapienza, and L. Zingales. 2009. “Cultural Biases in Economic Exchange?.” The Quarterly Journal of Economics 124 (3):1095-131.

Hagn, F., and W. Maennig. 2008. "Employment Effects of the Football World Cup 1974 in Germany." Labour Economics 15 (5):1062-75. 
Hatzigeorgiou, A. 2010. "Migration as Trade Facilitation: Assessing the Links Between International Trade and Migration." The B.E. Journal of Economic Analysis \& Policy 10 (1):Article 24.

Head, K., and J. Ries. 1998. "Immigration and Trade Creation: Econometric Evidence from Canada." The Canadian Journal of Economics 31 (1):47-62.

Head, K., and J. Ries. 2010. "Do Trade Missions Increase Trade?" Canadian Journal of Economics/Revue canadienne d'économique 43 (3):754-775.

Heckman, J. J. 1979. "Sample Selection Bias as a Specification Error." Econometrica 47 (1):153-61. Helpman, E., and P. Krugman. 1985. Market Structure and Foreign Trade. Cambridge, MA: MIT Press. Helpman, E., M. Melitz, and Y. Rubinstein. 2008. "Estimating Trade Flows: Trading Partners and Trading Volumes.” The Quarterly Journal of Economics 123 (2):441-87.

Herander, M., and L. Saavedra. 2005. "Exports and the Structure of Immigrant-Based Networks: The Role of Geographic Proximity." Review of Economics and Statistics 87 (2):323-35.

Hofstede, G. 2001. Culture's Consequences: Comparing Values, Behaviors, Institutions, and Organizations Across Nations, 2nd ed. Thousand Oaks, CA: Sage Publications.

Hummels, D., and P. J. Klenow. 2005. "The Variety and Quality of a Nation's exports." American Economic Review 704-723.

Hummels, D., and G. Schaur. 2012. "Time as a Trade Barrier." National Bureau of Economic Research, Working Paper No. 17758.

Initiative, Futures Sport + Entertainment. 2007. "The Most Watched TV Sporting Events of 2006." ViewTrack Report.

Kneller, R., and M. Pisu. 2011. "Barriers to Exporting: What Are They and Who Do They Matter to?” The World Economy 34 (6):893-930.

Kulendran, N., and K. Wilson. 2000. "Is There a Relationship Between International Trade and International Travel?” Applied Economics 32 (8):1001-9.

Lederman, D., M. Olarreaga, and L. Payton. 2010. “Export Promotion Agencies: Do They Work?” Journal of Development Economics 91 (2):257-65.

Limao, N., and A. J. Venables. 2001. "Infrastructure, Geographical Disadvantage, Transport Costs, and Trade." The World Bank Economic Review 15 (3):451-79.

Martincus, C. V., and J. Carballo. 2010. "Entering New Country and Product Markets: Does Export Promotion Help?" Review of World Economics 146 (3):437-67.

Melitz, J. 2008. "Language and Foreign Trade." European Economic Review 52 (4):667-99.

Nitsch, V. 2007. "State Visits and International Trade." The World Economy 30 (12):1797-816.

OECD. 2009. Top Barriers and Drivers to SME Internationalization: Report by the Working Party on SMES and Entrepreneurship. Paris: OECD.

Rauch, J. E. 1999. “Networks Versus Markets in International Trade.” Journal of International Economics 48 (1):7-35.

Rauch, J. E. 2001. "Business and Social Networks in International Trade." Journal of Economic Literature 39 (4):1177-203.

Rauch, J. E., and V. Trindade. 2002. "Ethnic Chinese Networks in International Trade." Review of Economics and Statistics 84 (1):116-30.

Rose, A. K. 2007. "The Foreign Service and Foreign Trade: Embassies as Export Promotion.” The World Economy 30 (1):22-38.

Rose, A. K., and M. M. Spiegel. 2011. "The Olympic Effect." The Economic Journal 121 (553):652-77. Santos Silva, J., and S. Tenreyro. 2006. "The Log of Gravity." The Review of Economics and Statistics 88 (4):641-58. 
Schneider, S. 1988. "National vs. Corporate Culture: Implications for Human Resource Management." Human Resource Management 27 (2):231-46.

Spaaij, R. 2012. "Olympic Rings of Peace? The Olympic Movement, Peacemaking and Intercultural Understanding." Sport in Society 15 (6):761-74.

Sterken, E. 2006. "Growth Impact of Major Sporting Events." European Sport Management Quarterly 6 (4):375-89.

Swedish National Board of Trade. 2011. What are the Barriers to Sweden's Foreign Trade? An Analysis of an Interview Survey of Swedish Companies. Stockholm: Kommerskollegium. United Press International. 1971. “UPI Year in Review 1970-1979.” United Press International. Accessed February 2012. www.upi.com.

Westerlund, J., and F. Wilhelmsson. 2011. "Estimating the Gravity Model Without Gravity Using Panel Data." Applied Economics 43 (6):641-9.

\section{Appendix}

Table 5: Variable description and data sources.

\begin{tabular}{|c|c|c|}
\hline $\begin{array}{l}\text { Variable } \\
\text { type }\end{array}$ & Description & Source \\
\hline Trade & Value of goods exported from country $i$ to country $j$ in natural logs. & $\mathrm{BACl}$ \\
\hline Sport & Number of soccer matches played between country $i$ and country $j$. & RSSF \\
\hline Geography & $\begin{array}{l}\text { Distance is the natural logarithm between main cities in } i \text { and } j \text {. } \\
\text { Adjacency equals one if } i \text { and } j \text { share a common national border, zero } \\
\text { otherwise. Landlocked equals one if } i \text { and } j \text { lack coastline or direct } \\
\text { access to sea, zero otherwise. }\end{array}$ & CEPII \\
\hline Culture & $\begin{array}{l}\text { Official language equals one if } i \text { and } j \text { have the same official } \\
\text { language, zero otherwise. Common religion equals one if } i \text { and } j \\
\text { share the same main religion, zero otherwise. }\end{array}$ & $\begin{array}{l}\text { CEPII, CIA } \\
\text { World } \\
\text { Factbook }\end{array}$ \\
\hline Institutions & $\begin{array}{l}\text { Colonial ties equals one if } i \text { and } j \text { were ever in a colonial relationship, } \\
\text { zero otherwise. Currently colony equals one if } i \text { and } j \text { currently are in } \\
\text { a colonial relationship, zero otherwise. Same country equals one if } i \\
\text { and } j \text { were or are the same country, zero otherwise. Currency union } \\
\text { equals one if } i \text { and } j \text { are in the same currency union, zero otherwise. } \\
\text { RTA equals one if } i \text { and } j \text { are in the same regional trade agreement, } \\
\text { zero otherwise. }\end{array}$ & $\begin{array}{l}\text { CEPII, } \\
\text { Glick and } \\
\text { Rose } \\
(2002)\end{array}$ \\
\hline
\end{tabular}


Table 6: Summary statistics.

\begin{tabular}{lrrrr}
\hline Variable & Mean & Std. Dev. & Min. & Max. \\
\hline Export & $142,389.4$ & 1991789 & 0 & $222,000,000$ \\
Soccer matches & 0.0319417 & 0.214718 & 0 & 6 \\
Distance & $8,514.416$ & $4,717.695$ & 10.47888 & 19904.45 \\
Contiguity & 0.0132959 & 0.114539 & 0 & 1 \\
Common language & 0.1711907 & 0.3766761 & 0 & 1 \\
Colony & 0.0103055 & 0.1009917 & 0 & 1 \\
Same region & 0.1413324 & 0.3483646 & 0 & 1 \\
RTA & 0.1264032 & 0.3323038 & 0 & 1 \\
Currency union & 0.0066512 & 0.0812836 & 0 & 1 \\
\hline
\end{tabular}

Table 7: Countries in the sample.

\begin{tabular}{llll}
\hline Afghanistan & Djibouti & Liberia & Senegal \\
Albania & Dominica & Libya & Seychelles \\
Algeria & Dominican Rep. & Lithuania & Sierra Leone \\
Andorra & East Timor & Macau & Singapore \\
Angola & Ecuador & Madagascar & Slovakia \\
Anguilla & Egypt & Malawi & Slovenia \\
Antigua/Barbuda & El Salvador & Malaysia & Solomon Is. \\
Argentina & Equatorial Guinea & Maldive Is. & Somalia \\
Armenia & Eritrea & Mali & South Africa \\
Aruba & Estonia & Malta & South Korea \\
Australia & Ethiopia & Marshall islands & Spain \\
Austria & FYR Macedonia & Mauritania & Sri Lanka \\
Azerbaijan & Falkland islands & Mauritius & St Kitts/Nevis \\
Bahamas & Fiji & Mexico & St Lucia \\
Bahrain & Finland & Micronesia & St Vincent and Gr. \\
Bangladesh & France & Moldova & St. Helena \\
Barbados & Gabon & Mongolia & St. Pierre and Miq. \\
Belarus & Gambia & Montserrat & Sudan \\
Belgium-Lux. & Georgia & Morocco & Suriname \\
Belize & Germany & Mozambique & Sweden \\
Benin & Ghana & Myanmar & Switzerland-Liech. \\
Bermuda & Gibraltar & Nauru & Syrian \\
Bhutan & Greece & Nepal & Tajikistan \\
Bolivia & Greenland & Neth. Antilles & Tanzania \\
Bosnia-Herzegovina & Grenada & Netherlands & Thailand \\
Brazil & Guatemala & New Caledonia & Togo \\
British Virgin I & Guinea & New Zealand & Tokelau \\
\hline
\end{tabular}


Table 7: (continued)

\begin{tabular}{llll}
\hline Brunei & Guinea-Bissau & Nicaragua & Tonga \\
Bulgaria & Guyana & Niger & Trinidad and Tobago \\
Burkina Faso & Haiti & Nigeria & Tunisia \\
Burundi & Honduras & Niue & Turkey \\
Cambodia & Hong Kong & Norfolk island & Turkmenistan \\
Cameroon & Hungary & North Korea & Turks and C. Is. \\
Canada & Iceland & Northern Mariana Is. & Tuvalu \\
Cape Verde Is. & India & Norway & UAE \\
Cayman & Indonesia & Oman & UK \\
Central African R & Iran & Pakistan & USA \\
Chad & Iraq & Palau & Uganda \\
Chile & Ireland & Panama & Ukraine \\
China & Israel & Papua New Guinea & Uruguay \\
Christmas island & Italy & Paraguay & Uzbekistan \\
Cocos Is. & Ivory Coast & Peru & Vanuatu \\
Colombia & Jamaica & Philippines & Venezuela \\
Comoro Is. & Japan & Pitcairn & Vietnam \\
Congo & Jordan & Poland & Wallis and Futuna Is. \\
Congo DR & Kazakhstan & Portugal & Western Sahara \\
Cook Islands & Kenya & Qatar & Yemen PR \\
Costa Rica & Kiribati & Romania & Yugoslavia (S\&M) \\
Croatia & Kuwait & Russia & Zambia \\
Cuba & Kyrgyzstan & Rwanda & Zimbabwe \\
Cyprus & Laos & Samoa & \\
Czech Republic & Latvia & Sao Tomé e Pr. & \\
Denmark & Lebanon & Saudi Arabia & \\
\hline
\end{tabular}


Table 8: OLS estimation results - region multi.

\begin{tabular}{|c|c|c|c|c|}
\hline & \multirow{2}{*}{$\begin{array}{r}(1) \\
\begin{array}{r}\text { Aggregate } \\
\text { exports }\end{array}\end{array}$} & (2) & (3) & (4) \\
\hline & & $\begin{array}{r}\text { Differentiated } \\
\text { goods }\end{array}$ & $\begin{array}{r}\text { Homogeneous } \\
\text { goods }\end{array}$ & $\begin{array}{r}\text { Friendly matches } \\
\text { excluded }\end{array}$ \\
\hline Soccer matches & $\begin{array}{l}0.188^{\star \star \star} \\
(0.025)\end{array}$ & $\begin{array}{l}0.194^{\star \star \star} \\
(0.023)\end{array}$ & $\begin{array}{l}0.165^{\star * \star} \\
(0.025)\end{array}$ & $\begin{array}{l}0.135^{\star \star \star} \\
(0.028)\end{array}$ \\
\hline Distance & $\begin{array}{l}-1.127^{\star \star \star} \\
(0.025)\end{array}$ & $\begin{array}{l}-1.197^{\star \star \star} \\
(0.024)\end{array}$ & $\begin{array}{l}-1.241^{\star \star \star} \\
(0.029)\end{array}$ & $\begin{array}{l}-1.199^{\star \star \star} \\
(0.026)\end{array}$ \\
\hline Adjacency & $\begin{array}{l}0.825^{\star \star \star} \\
(0.105)\end{array}$ & $\begin{array}{l}0.909^{\star \star \star} \\
(0.098)\end{array}$ & $\begin{array}{l}0.823^{\star \star \star} \\
(0.100)\end{array}$ & $\begin{array}{l}0.854^{\star \star \star} \\
(0.102)\end{array}$ \\
\hline Common language & $\begin{array}{l}0.678^{\star * \star} \\
(0.040)\end{array}$ & $\begin{array}{l}0.730^{\star \star \star \star} \\
(0.039)\end{array}$ & $\begin{array}{l}0.460^{\star \star \star} \\
(0.046)\end{array}$ & $\begin{array}{l}0.679^{\star \star \star} \\
(0.040)\end{array}$ \\
\hline Colonial relationship & $\begin{array}{l}1.109^{\star \star \star} \\
(0.096)\end{array}$ & $\begin{array}{l}0.984^{\star \star \star} \\
(0.094)\end{array}$ & $\begin{array}{l}1.138^{\star \star \star} \\
(0.091)\end{array}$ & $\begin{array}{l}1.098^{\star \star \star} \\
(0.097)\end{array}$ \\
\hline Same region & $\begin{array}{l}0.425^{\star \star \star} \\
(0.048)\end{array}$ & $\begin{array}{l}0.425^{\star \star \star} \\
(0.045)\end{array}$ & $\begin{array}{l}0.434^{\star \star \star} \\
(0.052)\end{array}$ & $\begin{array}{l}0.399^{\star \star \star} \\
(0.049)\end{array}$ \\
\hline RTA & $\begin{array}{l}0.523^{\star \star \star} \\
(0.036)\end{array}$ & $\begin{array}{l}0.491^{\star \star \star} \\
(0.035)\end{array}$ & $\begin{array}{l}0.426^{\star \star \star} \\
(0.040)\end{array}$ & $\begin{array}{l}0.504^{\star \star \star} \\
(0.037)\end{array}$ \\
\hline Currency union & $\begin{array}{l}0.407^{\star \star \star} \\
(0.117)\end{array}$ & $\begin{array}{l}0.640^{\star * \star} \\
(0.107)\end{array}$ & $\begin{array}{l}0.369^{\star \star \star} \\
(0.117)\end{array}$ & $\begin{array}{l}0.441^{\star \star \star \star} \\
(0.117)\end{array}$ \\
\hline Observations & 146,877 & 130,931 & 117,537 & 144,236 \\
\hline Adjusted $R^{2}$ & 0.733 & 0.763 & 0.647 & 0.734 \\
\hline
\end{tabular}

Exports (logarithm) is the dependent variable throughout. Robust standard errors in parentheses (clustering by country pairs). Importer and exporter specific fixed effects, year indicators and quasi-controls for time-variant multilateral trade resistances (region-reporter-year and region-partner-year indicators) are included in all regressions.

${ }^{\star} p<0.10,{ }^{\star *} p<0.05,{ }^{\star \star *} p<0.01$. 


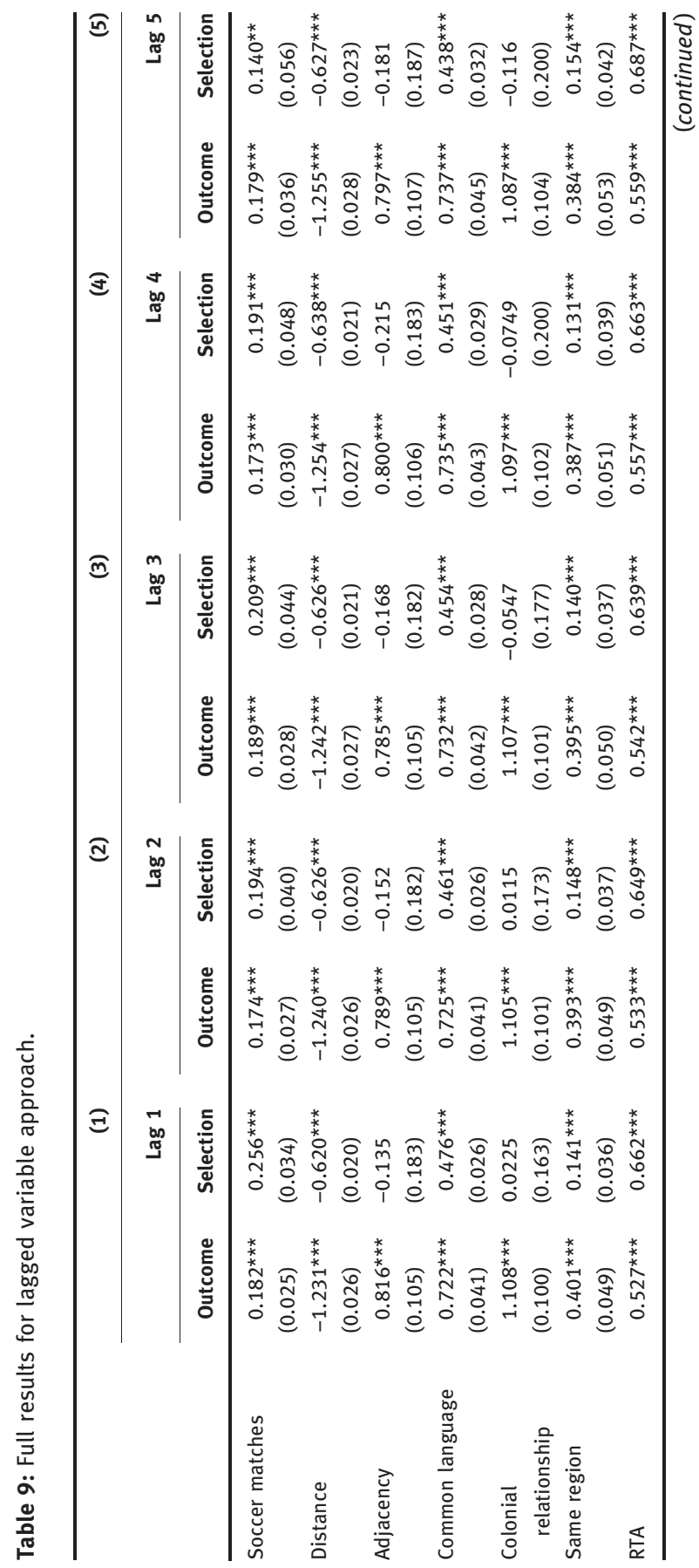




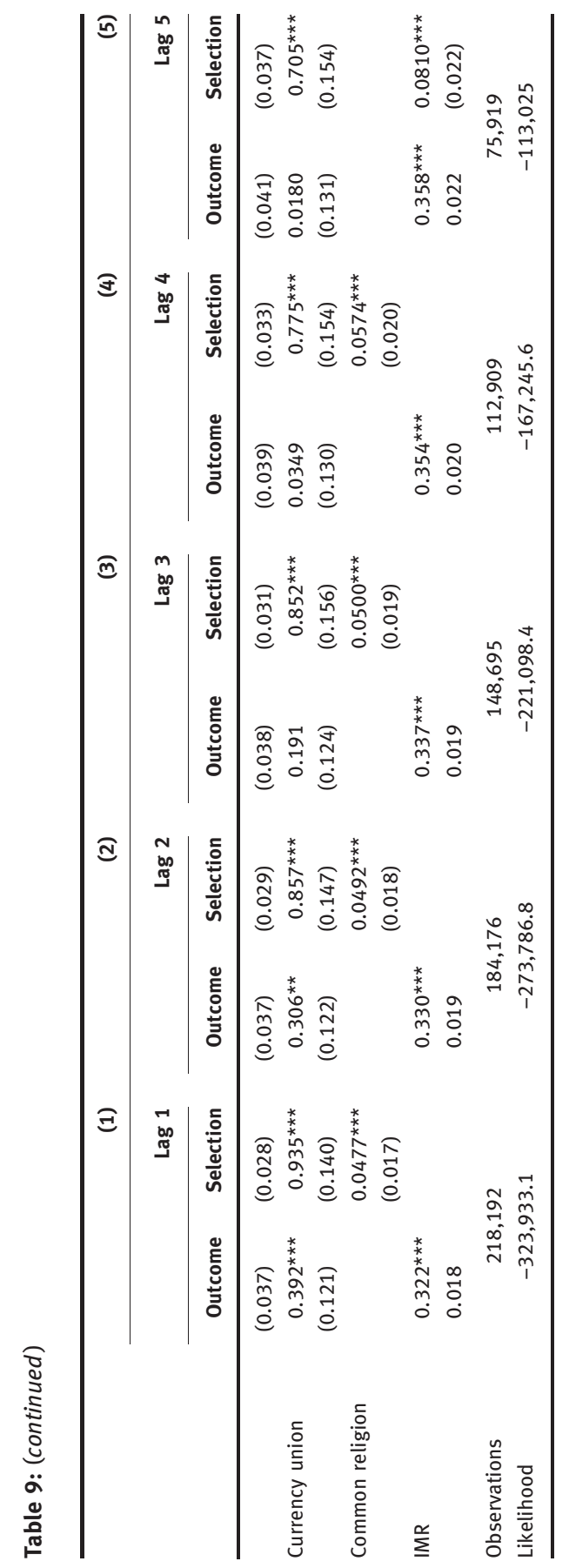

